\title{
Hydrogen sulfide prevents homocysteine-induced endoplasmic reticulum stress in PC12 cells by upregulating SIRT-1
}

\author{
CHUN-YAN WANG ${ }^{1 *}$, WEI ZOU ${ }^{2 *}$, XIAO-YU LIANG ${ }^{2,3}$, ZHI-SHENG JIANG $^{1}$, XIANG LI $^{3}$, \\ HAI-JUN WEI ${ }^{3}$, YI-YUN TANG ${ }^{3}$, PING ZHANG ${ }^{2}$ and XIAO-QING TANG ${ }^{2-4}$ \\ ${ }^{1}$ The Institute of Cardiovascular Disease, Medical College, ${ }^{2}$ Department of Neurology, Nanhua Affiliated Hospital, \\ ${ }^{3}$ Institute of Neuroscience, Medical College, University of South China; ${ }^{4}$ Hunan Province Cooperative Innovation Center for \\ Molecular Target New Drug Study, Hengyang, Hunan 421001, P.R. China
}

Received August 10, 2016; Accepted May 15, 2017

DOI: $10.3892 / \mathrm{mmr} .2017 .7004$

\begin{abstract}
It was previously confirmed that hydrogen sulfide $\left(\mathrm{H}_{2} \mathrm{~S}\right)$ has a neuroprotective effect, preventing homocysteine-induced neurotoxicity. However, the exact molecular mechanisms underlying this protective effect remain to be fully elucidated. Endoplasmic reticulum (ER) stress contributes to homocysteine-induced neurotoxicity. Silent mating type information regulator 2 homolog 1 (SIRT-1) can attenuate ER stress, exerting its neuroprotective effect. Therefore, the present study aimed to investigate whether $\mathrm{H}_{2} \mathrm{~S}$ protects PC12 cells against homocysteine-induced ER stress and whether SIRT-1 mediates this protective effect of $\mathrm{H}_{2} \mathrm{~S}$. Western blotting was used to detect the expression of SIRT-1, glucose-regulated protein 78 (GRP78), and cleaved caspase-12 in PC12 cells. It was observed that sodium hydrosulfide (NaHS), an exogenous $\mathrm{H}_{2} \mathrm{~S}$ donor, significantly attenuated the homocysteine-induced ER stress responses, including increases in the protein expression levels of GRP78 and cleaved caspase-12. Simultaneously, NaHS upregulated the expression of SIRT-1 and reversed the homocysteine-induced downregulation of SIRT-1 in PC12 cells. Sirtinol, a specific inhibitor of SIRT-1, eliminated the protective effects of $\mathrm{H}_{2} \mathrm{~S}$ in homocysteine-induced ER stress. These data indicated that $\mathrm{H}_{2} \mathrm{~S}$ prevented homocysteine-induced ER stress via enhancing the expression of SIRT-1. These findings offer novel insight into the protective mechanisms of $\mathrm{H}_{2} \mathrm{~S}$ against homocysteine-induced neurotoxicity.
\end{abstract}

Correspondence to: Professor Xiao-Qing Tang, Institute of Neuroscience, Medical College, University of South China, 28 West Changsheng Road, Hengyang, Hunan 421001, P.R. China

E-mail: tangxq-usc@qq.com

Professor Zhi-Sheng Jiang, The Institute of Cardiovascular Disease, Medical College, University of South China, 28 West Changsheng Road, Hengyang, Hunan 421001, P.R. China

E-mail: zsjiang2005@163.com

*Contributed equally

Key words: homocysteine, hydrogen sulfide, endoplasmic reticulum stress, silent mating type information regulator 2 homolog 1

\section{Introduction}

Homocysteine, a thiol-containing amino acid, is generated by the demethylation of methionine $(1,2)$. It has been established that an elevated level of circulating homocysteine is an independent risk factor for Alzheimer's disease (AD) (3-8), and there is increasing evidence that homocysteine directly causes neurotoxicity in multiple neuronal types (9-11). In addition, it is known that endoplasmic reticulum (ER) stress is closely associated with the development and pathology of AD, which has the typical characteristics of inclusion bodies, abnormal formation and misfolded protein aggregation (12-14). It has also been reported that homocysteine leads to ER stress in neuronal cells (15-18), which suggests that ER stress-mediated homocysteine-induced neurotoxicity may be vital in the pathogenesis of AD. Therefore, the suppression of ER stress may provide a promising approach for the treatment of homocysteine-dependent neurodegenerative diseases.

Hydrogen sulfide $\left(\mathrm{H}_{2} \mathrm{~S}\right)$ is considered to be a novel endogenous neuroprotectant (19-23). Of note, data from our previous study demonstrated that the disturbance of endogenous $\mathrm{H}_{2} \mathrm{~S}$ generation was involved in the neurotoxicity of homocysteine (24), and that $\mathrm{H}_{2} \mathrm{~S}$ ameliorated homocysteine induced-neurotoxicity (25), indicating the potential of $\mathrm{H}_{2} \mathrm{~S}$-based prevention and treatment for neuronal injury induced by homocysteine exposure. Based on the importance of ER stress in the neurotoxicity of homocysteine, the present study aimed to expand on current understanding of the protective effects of $\mathrm{H}_{2} \mathrm{~S}$ in homocysteine-elicited neurotoxicity by examining the effects of $\mathrm{H}_{2} \mathrm{~S}$ on homocysteine-induced ER stress and the underlying mechanisms.

Sirtuins are nicotinamide adenine dinucleotide-dependent histone deacetylases, which counter aging, having a broad spectrum of metabolic and stress-tolerance functions. Emerging evidence has confirmed that silent mating type information regulator 2 homolog 1 (SIRT-1), one of the seven mammalian sirtuins, is directly involved in the neuronal protective effect against cellular damage and stressful perturbations in neurological diseases, including AD (26-29), amyotrophic lateral sclerosis (28), Huntington's disease $(30,31)$ and Parkinson's disease (32). Furthermore, it has been reported that SIRT-1 mediates the neuroprotective effect of paliperidone against 
MK-801-induced neuronal damage (33) and hyperbaric oxygen preconditioning-induced ischemic tolerance in the rat brain (34). Of note, previous studies have suggested that SIRT-1 exhibits its beneficial effects in neuroprotection via alleviation of the ER stress response $(35,36)$. Therefore, the present study investigated whether SIRT-1 contributes to the protective effects of $\mathrm{H}_{2} \mathrm{~S}$ against homocysteine-induced ER stress.

The results of the present study revealed that $\mathrm{H}_{2} \mathrm{~S}$ prevented homocysteine-induced ER stress and increased the protein expression of SIRT-1 in PC12 cells. Sirtinol, a specific inhibitor of SIRT-1, eliminated the inhibitory effects of $\mathrm{H}_{2} \mathrm{~S}$ against homocysteine-induced ER stress in the PC12 cells. These findings indicated that $\mathrm{H}_{2} \mathrm{~S}$ protects $\mathrm{PC} 12$ cells against homocysteine-induced ER stress via upregulating the expression of SIRT-1.

\section{Materials and methods}

Materials. Sodium hydrosulfide (NaHS), an exogenous donor of $\mathrm{H}_{2} \mathrm{~S}$, homocysteine and sirtinol, a specific inhibitor of SIRT-1, were supplied by Sigma-Aldrich (cat. no. S7942; Merck KGaA, Darmstadt, Germany). Specific antibody against SIRT-1 (cat. no. ab110304) was purchased from Abcam (Cambridge, UK). Specific antibody against glucose-regulated protein 78 (GRP78; cat. no. S1931) was obtained from Epitomics (Burlingame, CA, USA). Specific antibody against cleaved caspase-12 (cat. no. C7611) was supplied by Sigma-Aldrich (Merck KGaA); $\beta$-actin polyclonal antibody (cat. no. 20536-1-AP) and goat anti-rat immunoglobulin (Ig)G (cat. no. SA00001-2) or goat anti-mouse IgG (cat. no. SA00001-1) antibody were obtained from ProteinTech Group, Inc. (Chicago, IL, USA). RPMI-1640 medium, fetal bovine serum (FBS) and horse serum were obtained from Gibco; Thermo Fisher Scientific, Inc. (Waltham, MA, USA).

Cell culture. The PC12 cells (American Type Culture Collection; CRL-1721), provided by Sun Yat-sen University Experimental Animal Center (Guangzhou, China), were cultured in RPMI-1640 medium supplemented with $10 \%(\mathrm{v} / \mathrm{v})$ heat-inactivated horse serum and $5 \% \mathrm{FBS}(\mathrm{v} / \mathrm{v})$ at $37^{\circ} \mathrm{C}$, in an atmosphere containing $5 \% \mathrm{CO}_{2}$ and $95 \%$ air. The culture medium was replaced every 2-3 days.

Western blot analysis. The PC12 cells, treated as described above, were homogenized in radioimmunoprecipitation assay buffer (Beyotime Institute of Biotechnology, Shanghai, China) containing phenylmethylsulphonyl fluoride $(1 \mathrm{mM})$ for $30 \min 4^{\circ} \mathrm{C}$ and the supernatants was obtained by centrifugation at 5,000 $\mathrm{xg}$ for $10 \mathrm{~min}$ at $4^{\circ} \mathrm{C}$. Protein concentrations were determined using a bicinchoninic acid protein assay kit (Beyotime Institute of Biotechnology). Equivalent quantities of protein $(50 \mu \mathrm{g})$ were separated by SDS-PAGE on a $12 \%$ gel. The proteins were then transferred onto polyvinylidene fluoride membranes, and the membranes were blocked with 5\% skim milk in Tris-buffered saline containing $0.1 \%$ Tween-20 (TBST) for $2 \mathrm{~h}$ at room temperature. The membranes were then incubated with primary antibodies specific for blocking solution, containing primary antibodies against SIRT-1 $(1: 2,000), \operatorname{GRP} 78(1: 2,000)$, cleaved caspase-12 $(1: 2,000)$ and $\beta$-actin $(1: 5,000)$ overnight at $4^{\circ} \mathrm{C}$. Following washing with
TBST three times, the membranes with SIRT-1 were incubated in peroxidase-conjugated affinipure goat anti-mouse $\operatorname{IgG}$ $(1: 5,000)$ and others were incubated in anti-rabbit secondary antibodies $(1: 5,000)$ in blocking solution for $2 \mathrm{~h}$ at $25^{\circ} \mathrm{C}$ and then washed in TBST buffer. The bands of protein were visualized using an enhanced chemiluminescence reaction solution (solution 1:0.1 M Tris-HCl, luminol and p-coumaric acid; solution 2:0.1 M Tris- $\mathrm{HCl}$ and hydrogen peroxide) for $2 \mathrm{~min}$, and quantified using an image analysis system equipped withBIO-1D software (v4.62; VilberLourmat, Marne-la-Vallée, France).

Statistical analysis. Data are expressed as the mean \pm standard error of the mean. The significance of differences in different groups was assessed using one-way analyses of variance followed by the least significant difference test using SPSS version 19.0 (IBM Corp., Armonk, NY, USA). P<0.05 was considered to indicate a statistically significant difference.

\section{Results}

Homocysteine induces ER stress in PC12 cells. To investigate whether homocysteine induces ER stress in PC12 cells, the present study measured the expression levels of ER stress-related proteins, including GRP78 and cleaved caspase-12, in homocysteine-treated PC12 cells using western blot analysis. It was found that treatment with homocysteine $(1.25,2.5$ or $5 \mathrm{mM}$ for $24 \mathrm{~h})$ significantly increased the expression levels of GRP78 (Fig. 1A) and cleaved caspase-12 (Fig. 1B) in the PC12 cells, which indicated that homocysteine-induced ER stress in the PC12 cells.

$\mathrm{H}_{2} \mathrm{~S}$ protects $\mathrm{PC} 12$ cells from homocysteine-induced ER stress. To determine whether $\mathrm{H}_{2} \mathrm{~S}$ protects $\mathrm{PC} 12$ cells against homocysteine-induced ER stress, the present study examined the effects of $\mathrm{H}_{2} \mathrm{~S}$ on the protein levels of GRP78 and cleaved caspase-12 in homocysteine-exposed PC12 cells. As shown in Fig. 2, cotreatment of the PC12 cells with NaHS (200 or $400 \mu \mathrm{M})$ significantly downregulated the expression levels of GRP78 (Fig. 2A) and cleaved caspase-12 (Fig. 2B), compared with the cells treated with $5 \mathrm{mM}$ of homocysteine for $24 \mathrm{~h}$. This indicated that $\mathrm{H}_{2} \mathrm{~S}$ had a protective effect in homocysteine-induced ER stress.

$\mathrm{H}_{2} \mathrm{~S}$ upregulates the expression of SIRT-1 in PC12 cells. As shown in Fig. 3A, treatment with homocysteine $(1.25,2.5$ or $5 \mathrm{mM}$, for $24 \mathrm{~h}$ ) significantly decreased the expression levels of SIRT-1 in the PC12 cells, which indicated that homocysteine downregulated the protein expression of SIRT-1 in PC12 cells. Treatment with NaHS at concentrations of 200 and $400 \mu \mathrm{M}$ for $24 \mathrm{~h}$ dose-dependently increased the expression of SIRT-1 in the PC12 cells (Fig. 3B), and also significantly increased the expression of SIRT-1 in the homocysteine-exposed $(5 \mathrm{mM}$ for $24 \mathrm{~h}$ ) PC12 cells (Fig. 3C), which indicated the promoting effect of $\mathrm{H}_{2} \mathrm{~S}$ on the expression of SIRT-1 in PC12 cells.

Inhibition of SIRT-1 eliminates the beneficent effect of $\mathrm{H}_{2} \mathrm{~S}$ against homocysteine-induced ER stress in PC12 cells. To further investigate whether the protective effect of $\mathrm{H}_{2} \mathrm{~S}$ on homocysteine-induced ER stress in PC12 cells was through the upregulation of SIRT-1, the present study used sirtinol, 
A

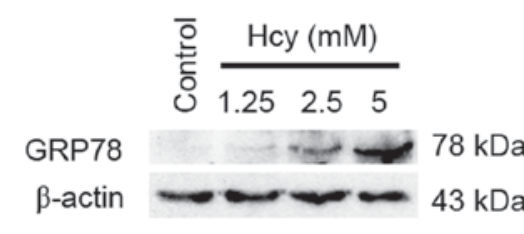

B

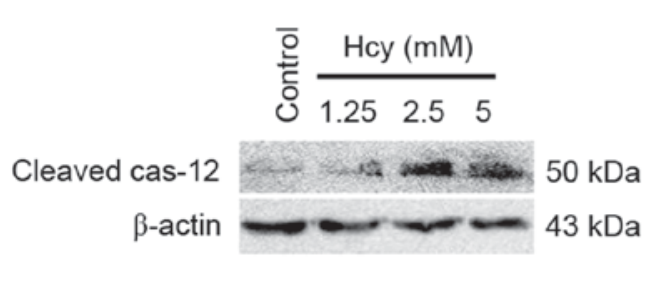

Figure 1. Hcy increases the protein expression levels of GRP78 and cleaved caspase-12 in PC12 cells. PC12 cells were treated with Hcy (1.25, 2.5 and 5 mM) for $24 \mathrm{~h}$. The protein expression levels of (A) GRP78 and (B) cleaved caspase-12 in PC12 cells were measured using western blot analysis. $\beta$-actin was used as a loading control. The results were normalized to the percentage of $\beta$-actin and expressed as the fold of the control group. Values are expressed as the mean \pm standard error of the mean of three independent experiments. ${ }^{*} \mathrm{P}<0.05$ and ${ }^{* *} \mathrm{P}<0.01$, compared with the control group. Hcy, homocysteine; GRP78, glucose-regulated protein 78 ; cas-12, caspase- 12 .

A
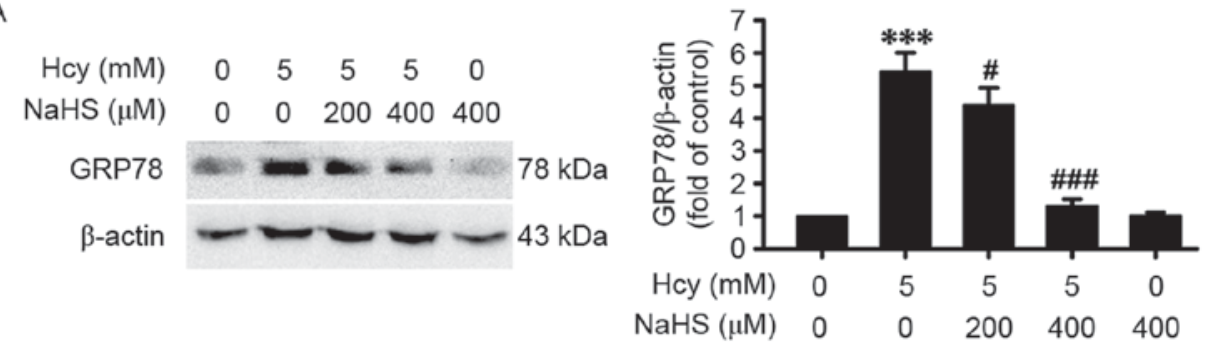

B
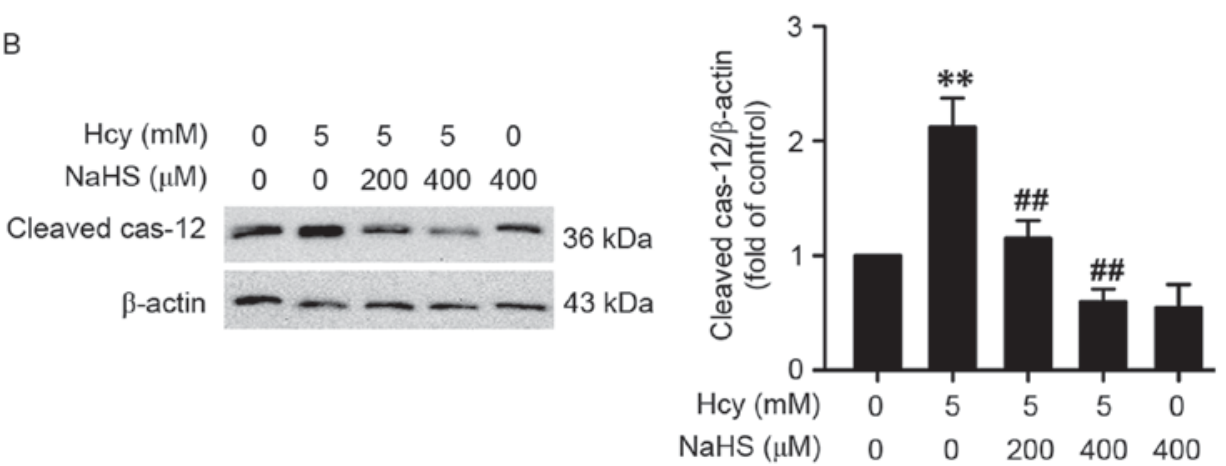

Figure 2. NaHS decreases endoplasmic reticulum stress in homocysteine-treated PC12 cells. Following cotreatment with NaHS (200 or $400 \mu \mathrm{M}$ ) and homocysteine $(5 \mathrm{mM})$ for $24 \mathrm{~h}$, the protein expression levels of (A) GRP78 and (B) cleaved caspase- 12 in PC12 cells were detected using western blot analysis. $\beta$-actin was used as a loading control. The results were normalized to the percentage of $\beta$-actin and expressed as the fold of the control group. Values are expressed as the mean \pm standard error of the mean of three independent experiments. ${ }^{* *} \mathrm{P}<0.01$ and ${ }^{* * *} \mathrm{P}<0.001$, compared with the control group; ${ }^{*} \mathrm{P}<0.05$, ${ }^{\# \#} \mathrm{P}<0.01$ and

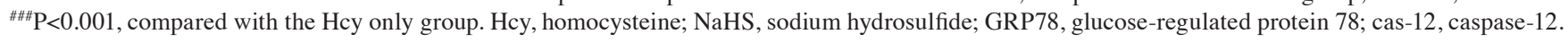

a specific inhibitor of SIRT-1, to examine the effect of H2S on ER stress under homocysteine treatment. The PC12 cells were pretreated with sirtinol $(15 \mu \mathrm{M})$ for $30 \mathrm{~min}$ prior to the administration of NaHS $(200 \mu \mathrm{M})$. The results demonstrated that sirtinol $(15 \mu \mathrm{M})$ treatment inhibited the NaHS (200 $\mu \mathrm{M}$ )-induced suppression of GRP78 (Fig. 4A) and 
B

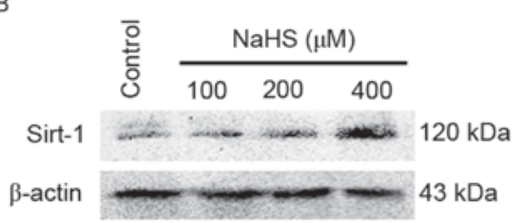



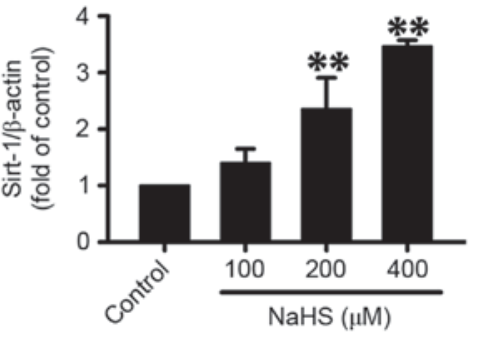

C
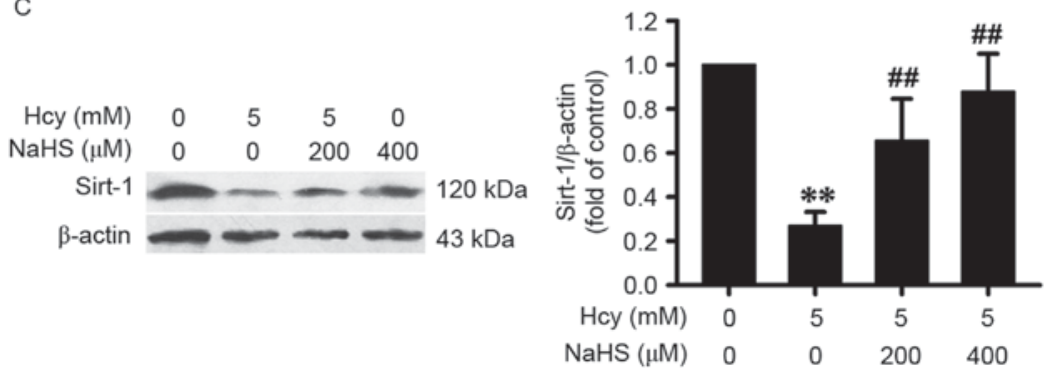

Figure 3. NaHS increases the protein expression of SIRT-1 in PC12 cells. (A) PC12 cells were incubated with Hcy (1.25, 2.5 or $5 \mathrm{mM})$ for 24 h. (B) PC12 cells were pretreated with NaHS (100, 200 or $400 \mu \mathrm{M})$ for $24 \mathrm{~h}$. (C) PC12 cells were co-treated with NaHS (200 or $400 \mu \mathrm{M})$ and Hcy $(5 \mathrm{mM})$ for $24 \mathrm{~h}$. The protein expression levels of SIRT-1 in PC12 cells were assessed using western blot analysis. $\beta$-actin was used as a loading control. The results were normalized to the percentage of $\beta$-actin and expressed as the fold of the control group. Values are expressed as the mean \pm standard error of the mean of three independent experiments. ${ }^{* *} \mathrm{P}<0.01$, compared with the control group; ${ }^{\# \#} \mathrm{P}<0.01$, compared with the Hcy only group. Hcy, homocysteine; NaHS, sodium hydrosulfide; SIRT-1 silent mating type information regulator 2 homolog 1 .

A

\begin{tabular}{|c|c|c|c|c|c|}
\hline Hcy (mM) & 0 & 5 & 5 & 5 & 0 \\
\hline $\mathrm{NaHS}(\mu \mathrm{M})$ & 0 & 0 & 400 & 400 & 0 \\
\hline Sirtionl (nM) & 0 & 0 & 0 & 20 & 20 \\
\hline
\end{tabular}

B

$\begin{array}{llllll}\mathrm{Hcy}(\mathrm{mM}) & 0 & 5 & 5 & 5 & 0\end{array}$

$\mathrm{NaHS}(\mu \mathrm{M}) \quad 0 \quad 0 \quad 400400 \quad 0$

Sirtionl (nM) $\quad 0 \quad 0 \quad 0020 \quad 20$

Cleaved cas-12

$\beta$-actin $-23 \mathrm{kDa}$
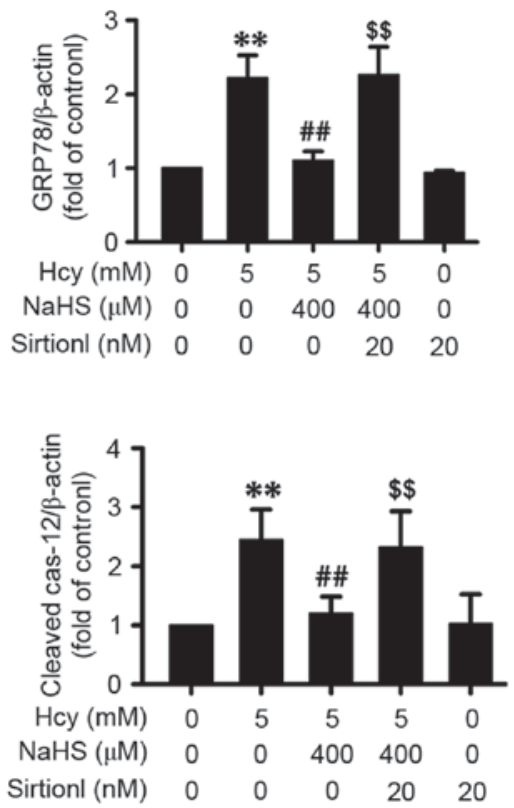

Figure 4. Sirtinol, a specific SIRT-1 inhibitor, reverses hydrogen sulfide-induced endoplasmic reticulum stress in Hcy-treated PC12 cells. PC12 cells were pre-incubated with sirtinol $(15 \mu \mathrm{M})$ for $30 \mathrm{~min}$ prior to cotreatment with NaHS (400 $\mu \mathrm{M})$ and Hcy $(5 \mathrm{mM})$ for $24 \mathrm{~h}$. The protein expression levels of (A) GRP78 and (B) cleaved caspase-12 in PC12 cells were measured using western blot analysis, respectively. $\beta$-actin was used as a loading control. The results were normalized to the percentage of $\beta$-actin and expressed as the fold of the control group. Values are expressed as the mean \pm standard error of the mean of three independent experiments. ${ }^{* *} \mathrm{P}<0.01$, compared with the control group; ${ }^{\# \#} \mathrm{P}<0.01$, compared with the Hcy only group; ${ }^{\text {\$s }} \mathrm{P}<0.01$, compared with the NaHS and Hcy cotreatment group. Hcy, homocysteine; NaHS, sodium hydrosulfide; SIRT-1 silent mating type information regulator 2 homolog 1; GRP78, glucose-regulated protein 78 ; cas-12, caspase-12. 
cleaved caspase-12 (Fig. 4B) in the homocysteine-exposed PC12 cells. Treatment with sirtinol alone did not affect the expression of these two proteins. These results indicated that the inhibition of SIRT-1 eliminated the protective effect of $\mathrm{H}_{2} \mathrm{~S}$ against homocysteine-induced ER stress.

\section{Discussion}

In our previous study, it was demonstrated that $\mathrm{H}_{2} \mathrm{~S}$ had a protective effect against homocysteine-induced neurotoxicity (25). In addition, the involvement of abnormal ER stress has been shown to be prominent in the neurotoxicity of homocysteine $(15,16)$. Therefore, the present study was designed to investigate whether the protective role of $\mathrm{H}_{2} \mathrm{~S}$ in the neurotoxicity of homocysteine was associated with regulating neuronal ER stress, and the underlying mechanisms were investigated. The main findings of the present study were as follows: i) $\mathrm{H}_{2} \mathrm{~S}$ markedly inhibited homocysteine-induced ER stress in the PC12 cells; ii) $\mathrm{H}_{2} \mathrm{~S}$ enhanced the protein level of SIRT-1 in the presence or absence of homocysteine treatment; and iii) sirtinol, an inhibitor of SIRT-1, eliminated the inhibitory effect of $\mathrm{H}_{2} \mathrm{~S}$ on homocysteine-induced ER stress. These findings suggested the protective role of $\mathrm{H}_{2} \mathrm{~S}$ against homocysteine-induced ER stress by enhancing the expression of SIRT-1.

Increasing evidence has confirmed the neurotoxic effects of homocysteine (37-40), which are associated with ER stress $(15,16)$. It is known that GRP78 is an ER-chaperone protein involved in the modulation of ER dynamic homeostasis $(41,42)$. Pro-caspase-12 is located on the cytoplasmic region of ER and is proteolytically activated during excess ER stress (43-45). GRP78 and caspase-12 are two important markers of ER stress. In the present study, the effects of homocysteine on the protein expression levels of GRP78 and cleaved caspase-12 in PC12 cells were examined. It was demonstrated that homocysteine upregulated the protein levels of GRP78 and cleaved caspase-12 in the $\mathrm{PC} 12$ cells. These results indicated that homocysteine was able to elevate ER stress in the PC12 cells. It is known that ER stress is involved in the pathogenic effects of homocysteine in several diseases, including cardiovascular disease (46), apoptosis of osteoblastic cells (47), insulin resistance of adipose tissue (48), and type 2 diabetes mellitus (49). Therefore, ER stress may be a common intermediate pathway in the homocysteine-induced pathogenic effects in tissues and cells.

$\mathrm{H}_{2} \mathrm{~S}$ is a protective gaseous signaling molecule. In our previous study, it was demonstrated that $\mathrm{H}_{2} \mathrm{~S}$ prevented homocysteine-induced neurotoxicity in PC12 cells (25). To improve current understanding of the protective role of $\mathrm{H}_{2} \mathrm{~S}$ in the neurotoxicity of homocysteine, the present study investigated whether $\mathrm{H}_{2} \mathrm{~S}$ suppresses the homocysteine-induced upregulatory effect on the expression levels of GRP78 and cleaved caspase-12. The results showed that NaHS (the donor of $\mathrm{H}_{2} \mathrm{~S}$ ) downregulated the expression levels of GRP78 and cleaved caspase-12 in the homocysteine-exposed PC12 cells, which indicated that $\mathrm{H}_{2} \mathrm{~S}$ was able to suppress homocysteine-induced ER stress. Previous studies have demonstrated that $\mathrm{H}_{2} \mathrm{~S}$ prevents ER stress in doxorubicin-induced cardiotoxicity (50) and 6-hydroxydopamine-induced neurotoxicity (51). These previous findings offer a reasonable explanation for the results obtained in the present study. Furthermore, Wei et al (46) revealed the protective effect of $\mathrm{H}_{2} \mathrm{~S}$ against homocysteine-induced cardiomyocytic ER stress. In the present study, the inhibitory role of $\mathrm{H}_{2} \mathrm{~S}$ in homocysteine-induced ER stress was further confirmed in the PC12 cells. Therefore, the regulation of ER stress offers insights into the protective effect of $\mathrm{H}_{2} \mathrm{~S}$ against homocysteine neurotoxicity.

The present study also examined the possible underlying signaling mechanisms for the protective effect of $\mathrm{H}_{2} \mathrm{~S}$ against homocysteine-induced ER stress. SIRT-1is involved in lifespan modulation (52-54) and orchestrates diverse biological processes, including cell survival, differentiation and metabolism $(55,56)$. SIRT-1 is considered to be a vital modulator of cellular defenses and survival in response to stress $(57,58)$. SIRT-1 is also expressed in the brain. Accumulating evidence has indicated that the upregulation of SIRT-1 rescues neurons in acute and chronic neurological diseases $(28,31,59)$. It has also been found that impaired SIRT1-deacetylation induces ER stress (60) and that the overexpression of SIRT-1 attenuates ER stress $(35,36)$. This suggests that SIRT-1 is important in counteracting ER stress, therefore, the present study focused on the effect of homocysteine on the expression of SIRT-1, and the role of $\mathrm{H}_{2} \mathrm{~S}$ in the expression of SIRT-1 in PC12 cells treated with or without homocysteine. The results showed that the expression of SIRT-1 was downregulated in the homocysteine-exposed PC12 cells, which indicated the involvement of downregulated SIRT-1 in the increase of ER stress induced by homocysteine. In addition, NaHS was found to increase the protein expression of SIRT-1 in PC12 cells. It was also found that NaHS inhibited the homocysteine-induced decrease in the protein expression of SIRT-1 in PC12 cells. These results suggested that the upregulation of SIRT-1 contributed to the beneficent effects of $\mathrm{H}_{2} \mathrm{~S}$ on homocysteine-induced ER stress. To confirm whether SIRT-1 mediates the protective effect of $\mathrm{H}_{2} \mathrm{~S}$ against homocysteine-induced ER stress, the present study examined whether the inhibition of SIRT-1 eliminates the protective effect of $\mathrm{H}_{2} \mathrm{~S}$ against ER stress induced by homocysteine. The results confirmed that the inhibition of SIRT-1 inhibited the reversal effect of $\mathrm{H}_{2} \mathrm{~S}$ on the homocysteine-increased protein expression of GRP78 and cleaved caspase-12 in PC12 cells. Taken together, these results suggested that the upregulation of SIRT-1 mediated the $\mathrm{H}_{2} \mathrm{~S}$-induced protective effects against homocysteine-induced ER stress.

In conclusion, the present study demonstrated that $\mathrm{H}_{2} \mathrm{~S}$ was able to overcome homocysteine-induced ER stress and increases in the protein expression of SIRT-1 in PC12 cells. Inhibiting SIRT-1 reversed the protective effect of $\mathrm{H}_{2} \mathrm{~S}$ against ER stress elicited by homocysteine in PC12 cells. These results suggested that $\mathrm{H}_{2} \mathrm{~S}$ had the ability to inhibit homocysteine-induced ER stress and that the upregulation of SIRT-1 mediated this protective effect of $\mathrm{H}_{2} \mathrm{~S}$. These findings shed light on the molecular mechanism underlying the protective role of $\mathrm{H}_{2} \mathrm{~S}$ in the neurotoxicity of homocysteine. Homocysteine is an independent risk factor for AD (3-7) and ER stress is a crucial process in the pathogenesis of AD (12-14). Therefore, the results of the present study suggested that positive intervention of SIRT-1 may have profound therapeutic benefits against homocysteine-dependent neurodegenerative diseases.

\section{Acknowledgements}

This study was supported by the Natural Science Foundation of China (grant nos. 81400881 and 81471310) and the Zhengxiang 
Scholar Program of University of South China (grant no. 2014-004).

\section{References}

1. Prudova A, Bauman Z, Braun A, Vitvitsky V, Lu SC and Banerjee R: S-adenosylmethionine stabilizes cystathionine beta-synthase and modulates redox capacity. Proc Natl Acad Sci USA 103: 6489-6494, 2006.

2. Selhub J: Homocysteine metabolism. Annu Rev Nutr 19: 217-246, 1999.

3. Van Dam F and Van Gool WA: Hyperhomocysteinemia and Alzheimer's disease: A systematic review. Arch Gerontol Geriatr 48: 425-430, 2009.

4. Seshadri S, Beiser A, Selhub J, Jacques PF, Rosenberg IH, D'Agostino RB, Wilson PW and Wolf PA: Plasma homocysteine as a risk factor for dementia and Alzheimer's disease. N Engl J Med 346: 476-483, 2002.

5. Miller JW: Homocysteine and Alzheimer's disease. Nutr Rev 57: 126-129, 1999.

6. Clarke R, Smith AD, Jobst KA, Refsum H, Sutton L and Ueland PM: Folate, vitamin B12, and serum total homocysteine levels in confirmed Alzheimer disease. Arch Neurol 55: 1449-1455, 1998.

7. Dwyer BE, Raina AK, Perry G and Smith MA: Homocysteine and Alzheimer's disease: A modifiable risk? Free Radic Biol Med 36: 1471-1475, 2004

8. Sharma GS, Kumar T, Dar TA and Singh LR: Protein N-homocysteinylation: From cellular toxicity to neurodegeneration. Biochim Biophys Acta 1850: 2239-2245, 2015.

9. Lin N, Qin S, Luo S, Cui S, Huang G and Zhang X: Homocysteine induces cytotoxicity and proliferation inhibition in neural stem cells via DNA methylation in vitro. FEBS J 281: 2088-2096, 2014.

10. Abushik PA, Niittykoski M, Giniatullina R, Shakirzyanova A, Bart G, Fayuk D, Sibarov DA, Antonov SM and Giniatullin R: The role of NMDA and mGluR5 receptors in calcium mobilization and neurotoxicity of homocysteine in trigeminal and cortical neurons and glial cells. J Neurochem 129: 264-274, 2014.

11. Park YJ, Ko JW, Jang Y and Kwon YH: Activation of AMP-activated protein kinase alleviates homocysteine-mediated neurotoxicity in SH-SY5Y cells. Neurochem Res 38: 1561-1571, 2013.

12. Hoozemans JJ, Veerhuis R, Van Haastert ES, Rozemuller JM, Baas F, Eikelenboom P and Scheper W: The unfolded protein response is activated in Alzheimer's disease. Acta Neuropathol 110: $165-172,2005$

13. Salminen A, Kauppinen A, Suuronen T, Kaarniranta K and Ojala J: ER stress in Alzheimer's disease: A novel neuronal trigger for inflammation and Alzheimer's pathology. J Neuroinflammation 6 : 41, 2009.

14. Cornejo VH and Hetz C: The unfolded protein response in Alzheimer's disease. Semin Immunopathol 35: 277-292, 2013.

15. Althausen S and Paschen W: Homocysteine-induced changes in mRNA levels of genes coding for cytoplasmic- and endoplasmic reticulum-resident stress proteins in neuronal cell cultures. Brain Res Mol Brain Res 84: 32-40, 2000.

16. Chigurupati S, Wei Z, Belal C, Vandermey M, Kyriazis GA, Thiruma V, Arumugam TV and Chan SL: The homocysteineinducible endoplasmic reticulum stress protein counteracts calcium store depletion and induction of CCAAT enhancer-binding protein homologous protein in a neurotoxin model of Parkinson disease. J Biol Chem 284: 18323-18333, 2009.

17. Kim HJ, Cho HK and Kwon YH: Synergistic induction of ER stress by homocysteine and beta-amyloid in SH-SY5Y cells. J Nutr Biochem 19: 754-761, 2008.

18. Park YJ, Jang Y and Kwon YH: Protective effect of isoflavones against homocysteine-mediated neuronal degeneration in SH-SY5Y cells. Amino Acids 39: 785-794, 2010.

19. Zhou CF and Tang XQ: Hydrogen sulfide and nervous system regulation. Chin Med J (Engl) 124: 3576-3582, 2011.

20. Łowicka E and Beltowski J: Hydrogen sulfide (H2S)-the third gas of interest for pharmacologists. Pharmacol Rep 59: 4-24, 2007.

21. Kimura H, Shibuya N and Kimura Y: Hydrogen sulfide is a signaling molecule and a cytoprotectant. Antioxid Redox Signal 17: 45-57, 2012.

22. Hu LF, Lu M, Hon Wong PT and Bian JS: Hydrogen sulfide: Neurophysiology and neuropathology. Antioxid Redox Signal 15 405-419, 2011.
23. Qu K, Lee SW, Bian JS, Low CM and Wong PT: Hydrogen sulfide: Neurochemistry and neurobiology. Neurochem Int 52: 155-165, 2008.

24. Tang XQ, Shen XT, Huang YE, Chen RQ, Ren YK, Fang HR, Zhuang YY and Wang CY: Inhibition of endogenous hydrogen sulfide generation is associated with homocysteine-induced neurotoxicity: Role of ERK1/2 activation. J Mol Neurosci 45: 60-67, 2011.

25. Tang XQ, Shen XT, Huang YE, Ren YK, Chen RQ, Hu B, He JQ, Yin WL, Xu JH and Jiang ZS: Hydrogen sulfide antagonizes homocysteine-induced neurotoxicity in PC12 cells. Neurosci Res 68: 241-249, 2010

26. Chen J, Zhou Y, Mueller-Steiner S, Chen LF, Kwon H, Yi S, Mucke L and Gan L: SIRT1 protects against microglia-dependent amyloid-beta toxicity through inhibiting NF-kappaB signaling. J Biol Chem 280: 40364-40374, 2005.

27. Qin W, Yang T, Ho L, Zhao Z, Wang J, Chen L, Zhao W, Thiyagarajan M, MacGrogan D, Rodgers JT, et al: Neuronal SIRT1 activation as a novel mechanism underlying the prevention of Alzheimer disease amyloid neuropathology by calorie restriction. J Biol Chem 281: 21745-21754, 2006.

28. Kim D, Nguyen MD, Dobbin MM, Fischer A, Sananbenesi F, Rodgers JT, Delalle I, Baur JA, Sui G, Armour SM, et al: SIRT1 deacetylase protects against neurodegeneration in models for Alzheimer's disease and amyotrophic lateral sclerosis. EMBO J 26: 3169-3179, 2007.

29. Donmez G, Wang D, Cohen DE and Guarente L: SIRT1 suppresses beta-amyloid production by activating the alpha-secretase gene ADAM10. Cell 142: 320-332, 2010.

30. Jeong H, Cohen DE, Cui L, Supinski A, Savas JN, Mazzulli JR, Yates JR III, Bordone L, Guarente L and Krainc D: Sirt1 mediates neuroprotection from mutant huntingtin by activation of the TORC1 and CREB transcriptional pathway. Nat Med 18: 159-165, 2012.

31. Jiang M, Wang J, Fu J, Du L, Jeong H, West T, Xiang L, Peng Q, Hou Z, Cai H, et al: Neuroprotective role of Sirtl in mammalian models of Huntington's disease through activation of multiple Sirt1 targets. Nat Med 18: 153-158, 2011.

32. Donmez G, Arun A, Chung CY, McLean PJ, Lindquist S and Guarente L: SIRT1 protects against $\alpha$-synuclein aggregation by activating molecular chaperones. J Neurosci 32: 124-132, 2012.

33. Zhu D, Zhang J, Wu J, Li G, Yao W, Hao J and Sun J: Paliperidone protects SH-SY5Y cells against MK-801-induced neuronal damage through inhibition of $\mathrm{Ca}(2+)$ influx and regulation of SIRT1/miR-134 signal pathway. Mol Neurobiol 53: 2498-2509, 2016.

34. Yan W, Fang Z, Yang Q, Dong H, Lu Y, Lei C and Xiong L: SirT1 mediates hyperbaric oxygen preconditioning-induced ischemic tolerance in rat brain. J Cereb Blood Flow Metab 33: 396-406, 2013.

35. Li Y, Xu S, Giles A, Nakamura K, Lee JW, Hou X, Donmez G, Li J, Luo Z, Walsh K, et al: Hepatic overexpression of SIRT1 in mice attenuates endoplasmic reticulum stress and insulin resistance in the liver. FASEB J 25: 1664-1679, 2011.

36. Jung TW, Lee KT, Lee MW and Ka KH: SIRT1 attenuates palmitate-induced endoplasmic reticulum stress and insulin resistance in HepG2 cells via induction of oxygen-regulated protein 150. Biochem Biophys Res Commun 422: 229-232, 2012.

37. Kuszczyk M, Gordon-Krajcer W and Lazarewicz JW: Homocysteine-induced acute excitotoxicity in cerebellar granule cells in vitro is accompanied by PP2A-mediated dephosphorylation of tau. Neurochem Int 55: 174-180, 2009.

38. Oldreive CE and Doherty GH: Neurotoxic effects of homocysteine on cerebellar Purkinje neurons in vitro. Neurosci Lett 413: 52-57, 2007.

39. Lipton SA, Kim WK, Choi YB, Kumar S, D'Emilia DM, Rayudu PV, Arnelle DR and Stamler JS: Neurotoxicity associated with dual actions of homocysteine at the N-methyl-D-aspartate receptor. Proc Natl Acad Sci USA 94: 5923-5928, 1997.

40. Bhatia P and Singh N: Homocysteine excess: Delineating the possible mechanism of neurotoxicity and depression. Fundam Clin Pharmacol 29: 522-528, 2015.

41. Ni M, Zhang Y and Lee AS: Beyond the endoplasmic reticulum: Atypical GRP78 in cell viability, signalling and therapeutic targeting. Biochem J 434: 181-188, 2011.

42. Lee AS: The ER chaperone and signaling regulator GRP78/BiP as a monitor of endoplasmic reticulum stress. Methods 35: 373-381, 2005.

43. Szegezdi E, Fitzgerald U and Samali A: Caspase-12 and ER-stressmediated apoptosis: The story so far. Ann N Y Acad Sci 1010: 186-194, 2003 
44. Nakagawa T, Zhu H, Morishima N, Li E, Xu J, Yankner BA and Yuan J: Caspase-12 mediates endoplasmic-reticulum-specific apoptosis and cytotoxicity by amyloid-beta. Nature 403: 98-103, 2000.

45. de la Cadena SG, Hernandez-Fonseca K, Camacho-Arroyo I and Massieu L: Glucose deprivation induces reticulum stress by the PERK pathway and caspase-7- and calpain-mediated caspase-12 activation. Apoptosis 19: 414-427, 2014

46. Wei H, Zhang R, Jin H, Liu D, Tang X, Tang C and Du J: Hydrogen sulfide attenuates hyperhomocysteinemia-induced cardiomyocytic endoplasmic reticulum stress in rats. Antioxid Redox Signal 12: 1079-1091, 2010.

47. Li Y, Zhang H, Jiang C, Xu M, Pang Y, Feng J, Xiang X, Kong W, $\mathrm{Xu}$ G, Li Y and Wang X: Hyperhomocysteinemia promotes insulin resistance by inducing endoplasmic reticulum stress in adipose tissue. J Biol Chem 288: 9583-9592, 2013.

48. Zbidi H, Redondo PC, López JJ, Bartegi A, Salido GM and López JJ: Homocysteine induces caspase activation by endoplasmic reticulum stress in platelets from type 2 diabetics and healthy donors. Thromb Haemost 103: 1022-1032, 2010.

49. Park SJ, Kim KJ, Kim WU, Oh IH and Cho CS: Involvement of endoplasmic reticulum stress in homocysteine-induced apoptosis of osteoblastic cells. J Bone Miner Metab 30: 474-484, 2012.

50. Wang XY, Yang CT, Zheng DD, Mo LQ, Lan AP, Yang ZL, Hu F, Chen PX, Liao XX and Feng JQ: Hydrogen sulfide protects H9c2 cells against doxorubicin-induced cardiotoxicity through inhibition of endoplasmic reticulum stress. Mol Cell Biochem 363 419-426, 2012
51. Xie L, Tiong CX and Bian JS: Hydrogen sulfide protects SH-SY5Y cells against 6-hydroxydopamine-induced endoplasmic reticulum stress. Am J Physiol Cell Physiol 303: C81-C91, 2012.

52. Canto $\mathrm{C}$ and Auwerx J: Caloric restriction, SIRT1 and longevity. Trends Endocrinol Metab 20: 325-331, 2009.

53. Bordone L and Guarente L: Calorie restriction, SIRT1 and metabolism: Understanding longevity. Nat Rev Mol Cell Biol 6: 298-305, 2005

54. Satoh A, Brace CS, Rensing N, Cliften P, Wozniak DF, Herzog ED, Yamada KA and Imai S: Sirtl extends life span and delays aging in mice through the regulation of Nk2 homeobox 1 in the DMH and LH. Cell Metab 18: 416-430, 2013.

55. Tang BL: SIRT1, neuronal cell survival and the insulin/IGF-1 aging paradox. Neurobiol Aging 27: 501-505, 2006.

56. Michan S and Sinclair D: Sirtuins in mammals: Insights into their biological function. Biochem J 404: 1-13, 2007.

57. Brunet A, Sweeney LB, Sturgill JF, Chua KF, Greer PL, Lin Y, Tran H, Ross SE, Mostoslavsky R, Cohen HY, et al: Stressdependent regulation of FOXO transcription factors by the SIRT1 deacetylase. Science 303: 2011-2015, 2004.

58. Milner J: Cellular regulation of SIRT1. Curr Pharm Des 15: 39-44, 2009.

59. Herskovits AZ and Guarente L: SIRT1 in neurodevelopment and brain senescence. Neuron 81: 471-483, 2014.

60. Ghemrawi R, Pooya S, Lorentz S, Gauchotte G, Arnold C, Gueant JL and Battaglia-Hsu SF: Decreased vitamin B12 availability induces ER stress through impaired SIRT1-deacetylation of HSF1. Cell Death Dis 4: e553, 2013. 